Jurnal Perikanan (2019) Volume 9. No. 2 : 125-129

DOI : https://doi.org/10.29303/jp.v9i2.148

\title{
PENGARUH PENAMBAHAN PROBIOTIK EM4 (Effective Microorganism) DENGAN DOSIS YANG BERBEDA PADA PAKAN TERHADAP HUBUNGAN PANJANG DAN BERAT IKAN MAS (Cyprinus carpio)
}

Effect of Addition of Probiotic EM4 (Effective microorganism) with Different Doses on Feed Against the Length and Weight Relationship of Carp (Cyprinus carpio)

\author{
Melda Karel ${ }^{1 *}$, Sitti Hilyana ${ }^{1)}$, Dewi Putri Lestari ${ }^{1)}$ \\ ${ }^{1)}$ Program Studi Budidaya Perairan, Universitas Mataram
}

\begin{abstract}
Abstrak
Penelitian ini bertujuan untuk mengetahui pengaruh penambahan probiotik komersil EM4 (Effective microorganism) terhadap hubungan panjang dan berat ikan mas (Cyprinus carpio). Penelitian ini menggunakan Rancangan Acak Lengkap dengan lima perlakuan, yakni P1 (tanpa penambahan probiotik), P2 (probiotik $10 \mathrm{ml} / \mathrm{kg}$ pakan), P3 (probiotik $15 \mathrm{ml} / \mathrm{kg}$ pakan), P4 (probiotik $20 \mathrm{ml} / \mathrm{kg}$ pakan), P5 (probiotik $25 \mathrm{ml} / \mathrm{kg}$ pakan) dan setiap perlakuan memiliki 3 ulangan sehingga total percobaan sebanyak 15 unit. Hasil penelitian menunjukkan bahwa terdapat pengaruh yang nyata $(\mathrm{p}>0,05)$ terhadap pertumbuhan panjang dan berat mutlak, sehingga dilakukan uji lanjut untuk mengetahui perlakuan terbaik dalam menghasilkan pertumbuhan panjang dan berat ikan mas, diketahui bahwa P3 (probiotik 15 $\mathrm{ml} / \mathrm{kg}$ pakan) merupakan perlakuan terbaik dalam penelitian ini.
\end{abstract}

Kata kunci : Probiotik, ikan mas, pertumbuhan, hubungan panjang dan berat.

\begin{abstract}
This research aimed to know the effect of the addition of commercial probiotics EM4 (Effective microorganism) to the length and weight relationship of carp (Cyprinus carpio). This study used a Completely Randomized Design with five treatments, namely P1 (without the addition of probiotics), P2 (probiotics $10 \mathrm{ml} / \mathrm{kg}$ of feed), P3 (probiotics $15 \mathrm{ml} / \mathrm{kg}$ of feed), P4 (probiotics $20 \mathrm{ml} / \mathrm{kg}$ of feed), P5 ( probiotics $25 \mathrm{ml} / \mathrm{kg}$ of feed) and each treatment has 3 replications so that the total experiment is 15 units. The results showed that there was a significant influence $(\mathrm{p}>0.05)$ on the growth of absolute length and weight, so that further tests were carried out to determine the best treatment to produce growth in length and weight of carp, note that P3 (probiotics $15 \mathrm{ml} / \mathrm{kg}$ of feed) is the best treatment in this study.
\end{abstract}

Keywords: Probiotics, carp, growth, long and heavy relationship.

*korespondensi : meldakarel1596@gmail.com 


\section{Pendahuluan}

Pengembangan budidaya Ikan Mas dapat membantu meningkatkan taraf hidup masyarakat, dapat pula memperluas lapangan pekerjaan dan dapat meningkatkan gizi masyarakat (Putri et al., 2016). Potensi areal budidaya air tawar di NTB memiliki luas 7.628,8 ha, namun tingkat pemanfaatan lahan baru mencapai $2.121,35$ ha atau sekitar (27,84\%) (Data Statistik Dinas Kelautan dan Perikanan NTB, 2013).

Dari hasil survey yang dilakukan di Desa Lingsar Kabupaten Lombok Barat diketahui bahwa beberapa pembudidaya Ikan Mas dapat menghabiskan pakan sebanyak 20-30 kg/bulannya. Pakan yang digunakan pada umumnya ialah pakan komersil yang menghabiskan sekitar 60$70 \%$ dari total biaya produksi yang dikeluarkan (Hamdani dkk. 2018). Pemanfaatan pakan oleh ikan sangat dipengaruhi oleh kualitas pakan dari segi kandungan nutrisi atau tingkat kecernaan pakan itu sendiri. Benih ikan air tawar pada umumnya memiliki sistem pencernaan yang masih sederhana dan masih membutuhkan pasokan enzim dari luar (Rimalia, 2016). Berdasarkan permasalahan diatas, maka dilakukan penelitian dengan menggunakan probiotik komersil EM4 yang dicampurkan pada pangan dengan cara penyemprotan. Pemberian probiotik dalam pakan dimaksudkan untuk meningkatkan daya cerna ikan terhadap pakan dengan meningkatkan enzim pencernaan yang dapat menghidrolisis protein menjadi senyawa lebih sederhana sehingga mudah diserap dan digunakan sebagai deposit untuk pertumbuhan (Lumbantu, 2018).

\section{Metode Penelitian}

Penelitian ini dilakukan di Instansi Pribadi Kota Mataram, NTB mulai tanggal 27 Mei sampai tanggal 26 Juni 2019.

Hewan uji yang digunakan yaitu Ikan Mas yang didapatkan dari pembudidaya di Desa Lingsar dengan jumlah ikan sebanyak 150 ekor dengan berat 9 - 12 gr, masing-masing perlakuan berisi 10 ekor.

Penelitian ini menggunakan metode Rancangan Acak Lengkap (RAL) satu faktor dengan 5 perlakuan dan masing masing perlakuan memiliki 3 ulangan. Taraf perlakuan penelitian ini ialah :

$\mathrm{P} 1$ : Penambahan probiotik $0 \mathrm{ml} / \mathrm{kg}$ pakan

$\mathrm{P} 2$ : Penambahan probiotik $10 \mathrm{ml} / \mathrm{kg}$ pakan

P3 : Penambahan probiotik $15 \mathrm{ml} / \mathrm{kg}$ pakan

P4 : Penambahan probiotik $20 \mathrm{ml} / \mathrm{kg}$ pakan

P5 : Penambahan probiotik $25 \mathrm{ml} / \mathrm{kg}$ pakan

\section{Analisis Data}

Parameter yang diamati dalam penelitan ini adalah laju pertumbuhan berat dan panjang mutlak $=\left(W_{t}-W_{o}\right),\left(L_{t}-L_{o}\right)$; hubungan panjang dan berat ikan $\mathrm{W}=\mathrm{a} \mathrm{L}^{\mathrm{b}}$. $\mathrm{W}_{\mathrm{o}}=$ bobot awal; $\mathrm{W}_{\mathrm{t}}=$ berat akhir; $L_{o}=$ panjang awal; $L_{t}=$ panjang akhir; $\mathrm{a}$ dan $\mathrm{b}=$ paramater. Berpengaruh tidaknya perlakuan ditentukan dengan analisis sidak ragam Anova, Apabila terdapat perbedaan antara perlakuan maka dilanjutkan dengan uji lanjut BNT, BNJ, dan Duncan, untuk menentukkan penggunaan uji lanjut dilihat berdasarkan nilai koefisien keseragaman.

\section{Hasil}

Berdasarkan penelitian yang telah dilakukan diperoleh data yaitu pertumbuhan mutlak dan hubungan panjang dan berat Ikan Mas.

\section{Laju Pertumbuhan Mutlak}

Berat mutlak merupakan pertambahan berat tubuh Ikan Mas selama waktu pemeliharaan. Berdasarkan hasil pengamatan pertumbuhan berat mutlak Ikan Mas selama 30 hari pemeliharaan menunjukkan adanya perbedaan hasil pada pakan yang diberi probiotik dengan pakan tanpa probiotik. Dapat dilihat pada Gambar 1. 


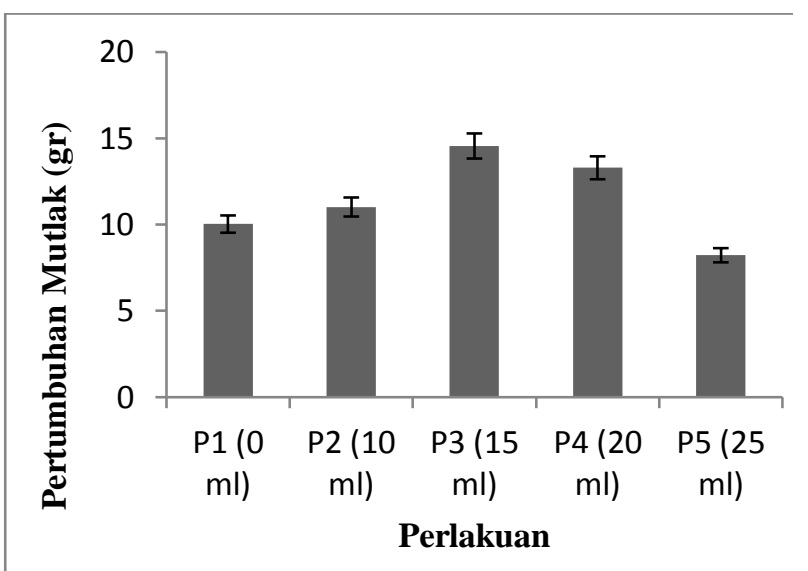

Gambar 1. Pertumbuhan Berat Mutlak

Dari Gambar 1. Dapat dilihat bahwa pertumbuhan berat mutlak perlakuan P3 merupakan perlakuan dengan berat mutlak tertinggi yakni sebesar 14,56 gram yang kemudian diikuti oleh $\mathrm{P} 4$ sebesar 13.29 gram, P2 sebesar 11,02 gram, P1 sebesar 10,03 gram, dan berat mutlak terendah terdapat pada perlakuan P5 sebesar 8,32 gram.

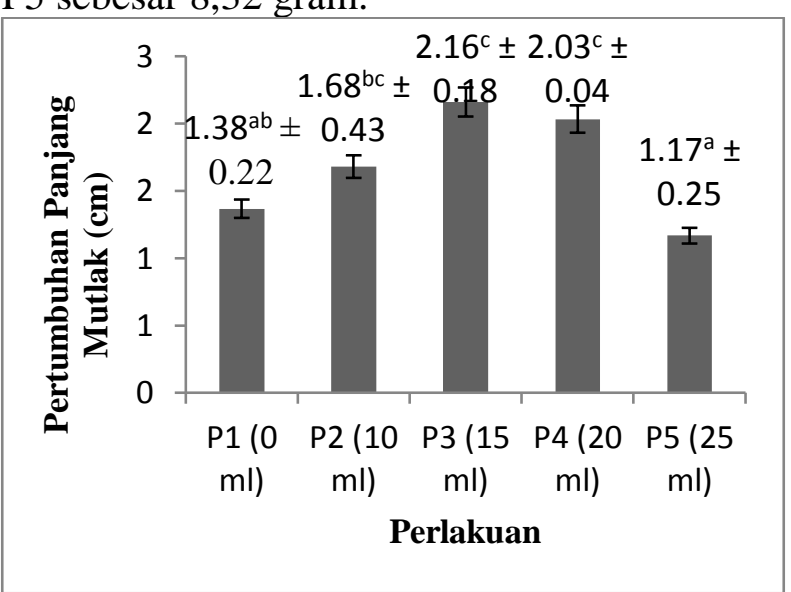

Gambar 7. Pertumbuhan Panjang Mutlak

Dari Gambar 7. Dapat dilihat bahwa pertumbuhan panjang mutlak perlakuan P3 sebesar 2,16 cm merupakan perlakuan dengan panjang mutlak tertinggi, kemudian diikuti oleh $\mathrm{P} 4$ sebesar 2,03 cm, P2 sebesar 1,68 cm, P1 sebesar $1,38 \mathrm{~cm}$, dan panjang mutlak terendah terdapat pada perlakuan P5 sebesar 1,17 $\mathrm{cm}$.

Hasil analisis sidik ragam menunjukkan bahwa penambahan probiotik pada pakan berpengaruh nyata ( $\mathrm{p}$ $<0,05)$ terhadap pertumbuhan berat mutlak
Ikan Mas, sehingga dilakukan uji lanjut Tukey untuk mengetahui perlakuan terbaik. Hasil uji lanjut menunjukkan bahwa perlakuan P1 berbedanya nyata dengan $\mathrm{P} 2, \mathrm{P} 3, \mathrm{P} 4$ dan $\mathrm{P} 5$, pertumbuhan berat mutlak tertinggi terdapat pada perlakuan P3 dengan dosis $15 \mathrm{ml} / \mathrm{kg}$ pakan, sedangkan hasil pertumbuhan berat mutlak terendah terdapat pada perlakuan P5 dengan dosis $25 \mathrm{ml} / \mathrm{kg}$ pakan. Hasil analisis sidik ragam pada pertumbuhan panjang mutlak yakni terdapat pengaruh yang nyata $(\mathrm{p}>0,05)$ sehingga dilakukan uji lanjut Tukey dan didapatkan hasil bahwa perlakuan P1 tidak berbeda nyata dengan P2 dan P5, namun berbeda nyata dengan P3 dan P4. Pertumbuhan panjang mutlak tertinggi terdapat pada perlakuan $\mathrm{P} 3$ dengan dosis probiotik $15 \mathrm{ml} / \mathrm{kg}$ pakan.

Terlihat pola pertumbuhan panjang dan berat mutlak perlakuan P4 dan P5 lebih rendah dibandingkan dengan perlakuan P3, hal ini diduga karena jumlah bakteri yang masuk dan tumbuh di dalam saluran pencernaan ikan lebih banyak dibandingkan perlakuan P3, hal ini juga diperkuat oleh Atlas dan Richard, (1993) dalam Arief et al., (2015) yang mengatakan bahwa kepadatan bakteri yang tinggi dapat menyebabkan terjadinya persaingan dalam pengambilan nutrisi sehingga membuat aktivitas bakteri menjadi terhambat. Mulyadi, (2011) dalam Arief et al., (2015) juga mengatakan bahwa penambahan jumlah bakteri pada pakan dengan jumlah yang terlalu banyak dapat menyebabkan bakteri lebih cepat mengalami sporulasi sehingga fungsi dan aktifitas dari bakteri Lactobacillus sp. menjadi tidak optimal dan proses penyerapan juga menjadi tidak maksimal.

Pada penelitian ini pakan yang diberi probiotik memiliki aroma atraktan yang disukai oleh ikan dan dapat merangsang ikan untuk mendekati makanan. Perlakuan P5 (probiotik 25 $\mathrm{ml} / \mathrm{kg}$ pakan) dengan pertumbuhan berat mutlak terendah juga diakibatkan karena sedikitnya tingkat konsumsi pakan akibat aroma pakan yang menjadi lebih kuat dan 
tidak disukai oleh Ikan Mas. Afrianto dan Liviawaty, (2015) dalam Noviana et al., (2014) berpendapat bahwa penambahan atraktan dengan jenis dan jumlah yang tepat dapat meningkatkan konsumsi pakan sehingga mampu meningkatkan pertumbuhan, sedangkan penambahan probiotik pada pakan dalam penelitian ini dengan perlakuan $\mathrm{P} 4$ (probiotik $20 \mathrm{ml} / \mathrm{kg}$ pakan) dan P5 (probiotik $25 \mathrm{ml} / \mathrm{kg}$ pakan) memiliki dosis probiotik yang dapat menyebabkan menurunnya laju pertumbuhan Ikan Mas, hal ini karena semakin banyak jumlah probiotik maka membuat semakin kuat aroma atraktan yang terdapat pada pakan dan aroma atraktan yang kuat membuat pakan tidak disukai oleh ikan.

\section{Hubungan Panjang dan Berat}

Hubungan panjang dan berat ikan bertujuan untuk mengetahui variasi berat dan panjang tertentu dari ikan secara individual atau kelompok dengan mendapatkan petunjuk mengenai kegemukan, kesehatan, produktifitas dan dan kondisi fisiologi dari ikan (Mulfizar et al., 2012). Penambahan probiotik komersil EM4 memiliki pengaruh meningkatkan nilai dalam hubungan panjang dan berat Ikan Mas. Dapat dilihat pada Tabel 1. berikut ini :

\begin{tabular}{cccccc}
\hline \multirow{2}{*}{$\begin{array}{c}\mathrm{P} 1 \\
\text { Parameter }\end{array}$} & $\begin{array}{c}\mathrm{P} 2 \\
\text { pakan })\end{array}$ & $\begin{array}{c}\text { (10 ml/kg } \\
\text { pakan) }\end{array}$ & $\begin{array}{c}\mathrm{P} 3 \\
(15 \mathrm{ml} / \mathrm{kg} \\
\text { pakan })\end{array}$ & $\begin{array}{c}\mathrm{P} 4 \\
(20 \mathrm{ml} / \mathrm{kg} \\
\text { pakan })\end{array}$ & $\begin{array}{c}\text { P5 } \\
(25 \mathrm{ml} / \mathrm{kg} \\
\text { pakan })\end{array}$ \\
\hline Panjang total $(\mathrm{cm})$ & $9,6-11,5$ & $9,7-11,5$ & $10,07-12,5$ & $10,3-12,2$ & $8,5-12,2$ \\
(rata-rata $\pm \mathrm{SD})$ & $10,5 \pm 0,09$ & $10,6 \pm 0,12$ & $11,4 \pm 0,03$ & $11,1 \pm 0,17$ & $10,1 \pm 0,09$ \\
Berat $(\mathrm{g})$ & $18,3-24,6$ & $17,9-24,9$ & $24,04-30,9$ & $22,9-29,3$ & $19,04-27,9$ \\
(rata-rata \pm SD) & $20,9 \pm 0,4$ & $21,4 \pm 0,5$ & $26,2 \pm 0,2$ & $24,4 \pm 0,4$ & $19,1 \pm 0,8$ \\
Indeks koefisien & 0,583 & 0,284 & 0,772 & 0,736 & 0,571 \\
diterminasi $\left(\mathrm{R}^{2}\right)$ & 3,655 & 2,645 & 5,680 & 4,633 & 2,555 \\
Nilai b & & & & & \\
\hline
\end{tabular}

Berdasarkan Tabel 1. di atas, dapat diketahui bahwa pertambahan berat Ikan Mas meningkat seiring dengan pertambahan panjang tubuh ikan. Untuk mengetahui hubungan panjang dan berat ikan dilakukan analisis dan didapatkan hubungan panjang dan berat perlakuan P3 memiliki nilai $b=5,680 x-38,66$, $k$ yang cenderung lebih tinggi dari perlakuan lainnya, perlakuan selanjutnya yakni P4 dimana $\mathrm{y}=4,633 \mathrm{x}-26,71$, kemudian $\mathrm{P} 1$ sebesar $\mathrm{y}=3,655 \mathrm{x}-17,53, \mathrm{P} 2$ dengan nilai $\mathrm{y}=2,645 \mathrm{x}-6,574$, dan P5 diamana $\mathrm{y}$ $=2,555 \mathrm{x}-6,734$.

Dari nilai di atas dapat diketahui bahwa Ikan Mas yang dipelihara selama 30 hari mengalami pertambahan berat cenderung lebih tinggi dibandingkan dengan pertambahan panjang, hal tersebut menunjukkan bahwa penambahan probiotik membuat hubungan berat dan panjang Ikan Mas meningkat, hubungan panjang dan berat pada P1 yakni dapat dilihat pada nilai $\mathrm{b}=3,655$ bersifat isometri yakni pertumbuhan berat dan panjang seimbang karena nilai $b$ sebesar atau sama dengan $3(b=3)$, pada perlakuan $\mathrm{P} 3$ dengan nilai $\mathrm{b}=5,680$ dan $\mathrm{P} 4$ dengan nilai $b=4,633$ bersifat allometrik positif yakni pertumbuhan berat lebih besar dari pertumbuhan panjang yang ditentukkan dari nilai $b$ yang lebih besar dari 3 (b>3), sedangkan perlakuan $\mathrm{P} 2$ dengan nilai $\mathrm{b}=$ 2,645 dan P5 dengan nilai $b=2,555$ bersifat allometrik negatif yakni pertambahan panjang lebih besar dibandingkan pertambahan berat karena nilai b kurang dari $3(\mathrm{~b}<3)$ (Wudji et al., 2012). dimana pada perlakuan P3 (probiotik $15 \mathrm{ml} / \mathrm{kg}$ pakan) memiliki nilai hubungan panjang berat tertinggi yakni 5,680. Sehingga dapat diketahui bahwa penambahan probiotik dalam pakan dengan dosis yang tepat yakni P3 
(probiotik $15 \mathrm{ml} / \mathrm{kg}$ pakan) mampu meningkatkan pertambahan berat lebih tinggi dibandingkan perlakuan lainnya.

\section{Kesimpulan}

Penambahan probiotik pada pakan Ikan Mas (Cyprinus carpio) memberikan pengaruh yang nyata terhadap hubungan panjang dan berat ikan Ikan Mas. Penambahan probiotik $15 \mathrm{ml} / \mathrm{kg}$ pakan merupakan dosis terbaik dalam menghasilkan pertumbuhan berat tertinggi efisiensi pakan. Penambahan probiotik mempengaruhi hubungan panjang dan berat Ikan Mas, P3 (Probiotik $15 \mathrm{ml} / \mathrm{kg}$ pakan) memiliki nilai $b$ tertinggi yakni 5,680 yang bersifat alometrik positif dimana pertambahan berat lebih cepat dibandingkan pertambahan panjang.

\section{Daftar Pustaka}

Arief M, Diatra F, Muhammad AA. 2015. Pengaruh Pemberian Probiotik Plus Herbal Pada Pakan Komersil Terhadap Retensi Protein dan Retensi Lemak Ikan Nila Merah (Oreochromis niloticus). Jurnal; Ilmiah Perikanan dan Kelautan 7(2), 207-212.
Lumbanbantu PA. 2018. Pengaruh Pemberian Probiotik EM4 Dalam Pakan Buatan Dengan Dosis Yang Berbeda Terhadap Pertumbuhan Dan Kelulushidupan Ikan Nila Merah (Oreochromis niloticus) Di Air Payau. Skripsi. Riau: Departemen Budidaya Perairan, Fakultas PerIkanan dan Kelautan, Universitas Riau.

Mulfizar, Zainal AM, Irma D. 2012. Hubungan Panjang Berat dan Faktor Kondisi Tiga Jenis Ikan yang Tertangkap di Perairan Kuala Gigieng, Aceh Besar, Provinsi Aceh. Depik. 1(1), 1-9.

Noviana P, Subandiyono, Pinandoyo. 2014. Pengaruh Pemberian Probiotik Dalam Pakan Buatan Terhadap Tingkat Konsumsi Pakan dan Pertumbuhan Benih Ikan Nila (Oreochromis niloticus). Journal of Aquaculture Management and Technology. 3(4), 183-190.

Wujdi A, Suwarso, Wudianto. 2012. Hubungan Panjang Bobot, Faktor Kondisi dan Struktur Ukuran Ikan Lemuru (Sardinella Lemuru Bleeker, 1853) di Perairan Selat Bali. Jurnal $\begin{array}{llll}\text { Bawal. } \quad 4 & \text { (2): }\end{array}$ 